\title{
China, Aspiration to Become a Football Superpower: What We Need to Know?
}

\author{
Jean Humbert, Wei Junying*, Camilo Burgos Villa, Gama Rivas Daru
}

School of Economics and Management, Yangtze University, Jingzhou, 434023, Hubei, China

*Corresponding author

Received: 11 December 2021 / Accepted: 14 January 2022 / Published: 05 March 2022

\begin{abstract}
The purpose of this paper is to find out the Chinese aspiration towards the football business, its risks, and challenges. Specifically, we examined the national and international Chinese investments in football. Our findings revealed that there is a tendency for China to offer a large sum of money to the foreign players to attract them but also to invest in infrastructure across the country in order to increase the population's interest in this sport. Imperative to know that, the state's asserted desire to become a great football nation, public and private companies must follow people's hope. It has been found that big football fans are involved in the development of football in China. The goal is to find the future Mbappé or Ronaldo who will allow China to shine as a football superpower.
\end{abstract}

Keywords: China, football, investments

\section{Introduction}

In the last decade, China is investing heavily in sport. One of the sports giving rise to the most hope for China and its investors, football is by far the most talked about. The most popular sport in the world and thus a sign of power is the new big goal of, the Middle Kingdom, a country that invented the ancestor of football, named cuju. [1]. The long-term strategy is clear and dictated by the Chinese authorities, to host the biggest event on earth and win the most coveted trophy. After winning the World Cup you enter in the very closed club of the 8 countries that lifted the trophy and the only 6 countries that won as a host. Your status in the world therefore changes. It is not surprising that the second most powerful country in the world is interested in football and it should not be minimized from a Western point of view either. Investors are keenly interested as the sport is increasingly popular with Chinese audiences and eye-catching to Western media always looking for new revenue. This new phenomenon can be analyzed through two aspects:

Chinese and European political factors; and the resulting risks, uncertainties, and issues that can be faced [1], [2]. The first part focuses on Chinese investment in European football through a strategy well defined by the Chinese authorities aimed at professionalizing this sport among these citizens. The second part examines these investments from a third-party perspective that allows the sport to grow and creates many risks, challenges, and opportunities to look out for.

\section{Chinese Investment in European and Chinese Football}

\subsection{The Aims of Investment}

We can observe that Chinese investments in European football are encouraged by the state which aims at the promotion and professionalization of football in China. The sport number 1 with its 250 million players and its 400 billion dollars are a prime target [3], [4]. In China, first of all, the strategy had two aims, expansion and investment, which moved the transfer market to Eastern Eurasia since at the start of the 2010s, the first players to have played at the highest European level, or even worldwide, settled in what is today one of the richest and most famous football clubs in the country: the Shanghai Greenland Shenhua Football Club. 


\subsection{Territories of Investment}

In Europe then, since 2014, the first Chinese capital investments in European football were directed towards two professional clubs playing respectively in Dutch Eredivisie (first division of the championship) and Italian Serie C (third division). In addition, between China and Europe since mid-February 2017, a French football office was inaugurated in Beijing. The latter seeks to develop its activities in this new territory, particularly in the field of training and aims to promote French football throughout the country. With more than 62 million Chinese viewers supporting the victory of Les Bleus in the 2018 World Cup final, this office is currently a success according to the Professional Football League (LFP). But France is far from being the only one. Before it, Spain opened its representative office in 2015, which led some clubs such as Bayern Munich and Manchester United to do the same. These representations make it possible to sign strategic agreements between the two countries [5]-[7]

With notably Chinese and European educational centers recently built in China, this last step represents the importation of knowledge as well as the key role of economic leaders interested in fulfilling the dream of Chinese President Xi Jinping. These three factors determine the three aspects of the scale and direction of Chinese investment in football. Buy the best players from Europe or with European football experience with the ultimate goal of bringing their experience and new visibility to the game, while promoting Chinese football [8].

During the transfer window of the summer of 2016, China entered the economic history of football a little further. Indeed, with 480 million dollars spent on transfers, the Chinese Super League (CSL) founded in 2004 was, in 2016, the fifth highest-spending league in purchases of foreign players; she was only in twentieth place in 2013. In this spending environment, it is not surprising that the biggest transfers have taken place in recent years.

The ten highest amounts of arrivals are all after the year 2014. Note that the Brazilians are popular because the three highest transfers are held by Brazilian players (Oscar, Hulk, and Teixera). It should also be noted that more than 40 Brazilian players play in the Chinese Super League, which shows the interest of clubs in having players from the country that has won the most World Cups. However, since July 2020 the Chinese Football Association has established regulations that limit the number of foreign football players who can play on the pitch to four or three players [9]. Three Chinese clubs monopolize Brazilian players: Shanghai Port FC, Jiangsu Suning, and Guangzhou Evergrande Taobao. The latter, eight-time winner of the national league is the richest and best known. According to a measure released in Beijing in 2016, Guangzhou Evergrande is 21.9 billion yuan (3.37 billion dollars) worth, far more than the market value of Manchester United which is 2.3 billion dollars. Its gigantic resources come from its two main shareholders Evergrande Real Estate Group (56.71\%), specializing in property development, and Alibaba (37.81\%), the Chinese ecommerce leader [9]-[12].

All these investments from the private and the public aim to professionalize this championship based on the European model. Clubs' ownership structures are willing to influence both investments and efficiency. New revenues from merchandising, ticketing, and above all broadcasting rights are making a great future to this championship. The most striking example is in the level of broadcasting rights with an amount worthy of European leaders such as the Italian championship. In 2015, China Sports Media acquired the Chinese league's broadcasting rights for 5 years for a pharaonic sum of 1.25 billion dollars and renewed its contract until 2025 to eventually reach 1.7 billion dollars [13], [14].

Chinese investments in Europe began in 2014 with Dutch club Den Haag. The Chinese company UVS becomes almost the sole shareholder by acquiring $98 \%$ of the capital. Despite these investments, the club never managed to play at the top of the table. The Chinese, through the investment fund Pingy Shanghai Investment, has also ventured into Italy, more specifically in the city of Pavia. Unfortunately, in 2015 the club was declared bankrupt and was demoted to Serie D, i.e. the Italian fourth division, angering the tifosis [15].

Nowadays, 21 European professional clubs have been the subject of Chinese investments. Among the 5 
Jean Humbert et al., Extsv. Rev.; Vol. 2, Issue 1, pp: 3-10, 2022

major leagues, 11 clubs, with well-known names such as Manchester City, Atletico Madrid, or the two Milan clubs (AC and Inter) have been targeted. In some cases, the shareholder is not the majority but for the clubs of Grenada, Lorca, Aston Villa, Wolverhampton and Sochaux they are Chinese properties. However, a country is spared. In fact, in Germany, it is forbidden for a foreign or German investor to become a majority shareholder. Only foreign sponsors can invest in the Bundesliga [16].

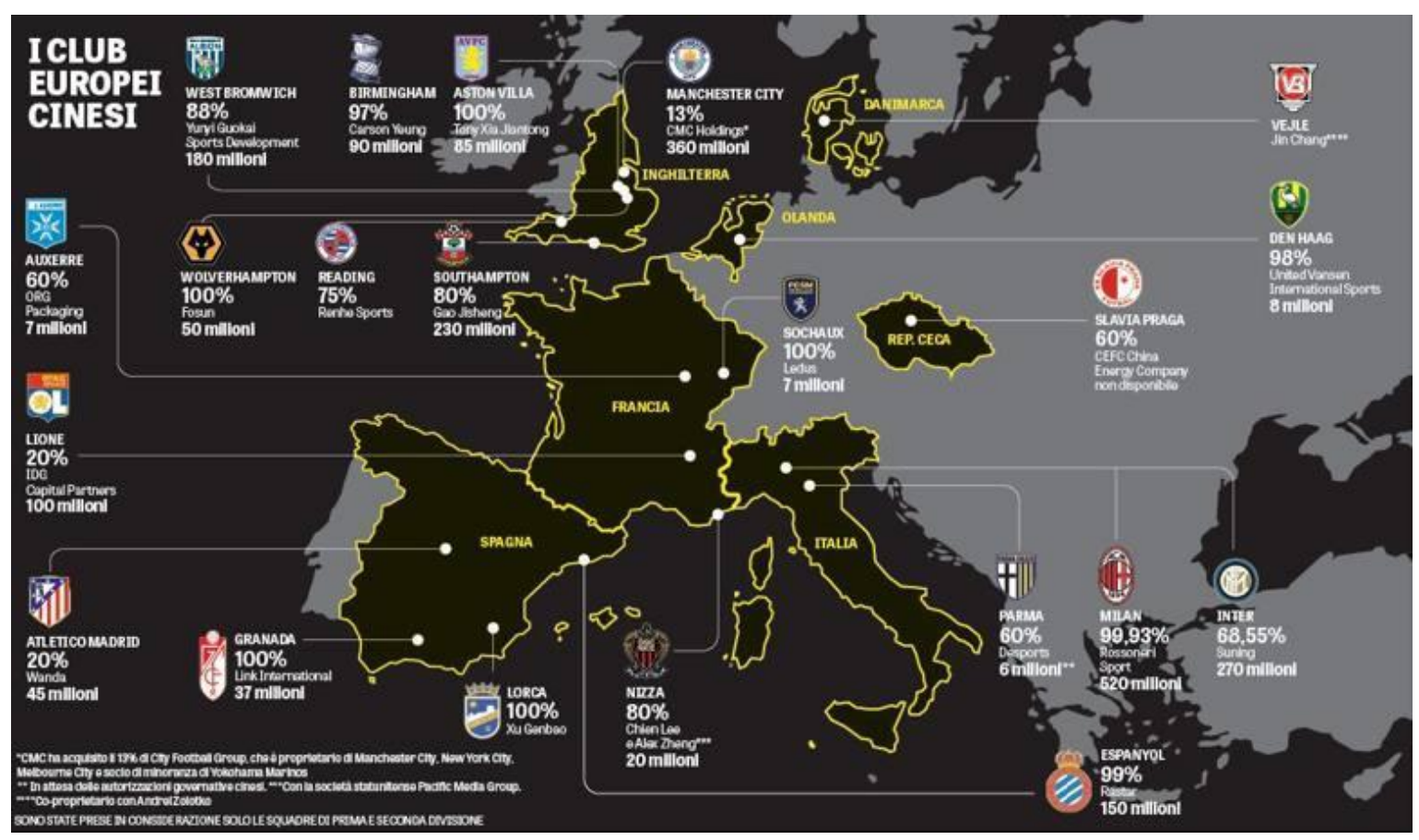

Map of the 'Chinese European clubs' Gazetta Dello Sport, August 27th, 2017. Marco Iaria Available from: https://www.gazzetta.it/Calcio/Serie-A/28-08-2017/geopolitica-pallone-frenata-cina-scenari-220167617035.shtml

\subsection{Advantages for China or Destination Countries of the Investment}

For China, these investments have many advantages. For example, the transfer of know-how will make it possible in the short term to improve the level of Chinese football. With, for example, a partnership between Real Madrid and Guangzhou Evergrande through the intermediary of the company Soxna which is responsible for managing the Real Madrid training schools located in China. Summer tours or training camps in Asia have also taken place, which improves the visibility of these championships and therefore the sales for example of shirts or the broadcasting rights of these teams. This is the case with Real Madrid C.F. which signed a contract with Alibaba allowing the site to be the only one to sell the club's merchandise. Then these investments help to build credibility and improve the image of these investors who can sometimes be seen as simple businessmen who are not involved in the club. For example, during the buyout of the Inter Milan club by the Suning Group, the new owner refunds the 270 million euros debt that the club had accumulated. A decision unanimously welcomed by the nerazzurris. Profiting from it politically, economically, and socially are the three reasons why Chinese investors direct their capital towards Europe. In total, more than 2.5 billion euros have been invested by various Chinese investors in European clubs until June 2020. However, two countries are concentrating these investments, $50 \%$ is made in Italy and $35 \%$ in England [17], [18].

Between China and the European continent, the import of know-how and the key role of Chinese economic leaders are important levers for increasing their expertise in this sport. From the Chinese national team trained by the Italian coach Marcello Lippi for 3 years to European coaches who came to coach in the Chinese Super League, the environment of European or Chinese players exchanging techniques and knowhow is wide. Coaching Guangzhou Evergrande (Fabio Cannavaro), Shanghai Port FC (Ivan Leko), Guangzhou City FC (Jean-Paul van Gastel), Beijing Guoan (Slaven Bilic), Henan Jianye (Javier Pereira) or 
Shenzhen FC (Jordi Cruyff), European coaches or having passed through Europe where they have acquired a knowledge of the game and at the same time popularity allow this league to progress. In total there are 8 foreign coaches (plus two South Koreans), meaning that half of the club trusts coaches from other countries. This shows the lack of confidence in Chinese coaches who may face certain footballing shortcomings.

However, the Chinese authorities, with the help of European football federations, are organizing seminars across Europe for Chinese sports teachers. These trainings allow them to learn tactics, ethics, and the fight against corruption. From an early age, young Chinese people learn football from trainers from Europe. This is the case at the Guangzhou Evergrande school which has recruited more than 20 trainers from Real Madrid.

Small investments can lead to big changes. This is what happened in the Portuguese second division the Ledman group became the new sponsor. They also cleverly included in the agreement the integration of Chinese players and coaches in the Portuguese clubs concerned to contribute to their respective formations. Previously called La Liga 2 Cabovisão has been renamed Ledman Ligapro. This group specializing in LED technology and sports is also associated with the Chinese Super League, a strategic partner of the Chinese second division (Jia League), and owner of the Australian football club Newcastle United Jets. It is also a major shareholder of Infront Sports and Media, the second-largest sports company in the world. Just a month after acquiring 20\% of the capital of Atletico Madrid, Wang Jialin, owner of the Dalian Wanda conglomerate and previously the biggest fortune in China, bought Infront for more than one billion euros. An influential company is responsible for the worldwide broadcast rights of FIFA events from 2015 to 2022. The ultimate goal is to create a global brand that can be easily exported. It was also in 2012 that he acquired the American AMC Theaters for 2.6 billion dollars and with the same occasion the gigantic network of theaters they have around the world. In 2016, the same group bought the Legendary studio, which produced Batman, Interstellar, or even Warcraft for 3.5 billion dollars. The cinema is, coupled with football a priority target. It is also a partner of the International Basketball and Football Federations (FIBA and FIFA). Thanks to these investments, the magnate built his empire around two criteria, sport and culture. The objective of Mr. Wang and the Wanda group is, alongside the Chinese authorities, to catch up with the West, especially in football. This is indeed the case with partnerships with FIFA or FIBA for basketball. For example, the Basketball World Cup which took place in China in 2019, the 2022 Winter Olympics in Beijing, and perhaps the 2030 Football World Cup are events that Mr. Wang and his group may consider popular with the public. Thanks to these investments, the Chinese as a whole become holders of foreign strategic assets. This allows them to be seen positively by the Chinese authorities and therefore to be encouraged to do more for the service of the country [19]-[21].

\section{Motivations, Risks, and Issues Linked to Chinese Investments in Football}

In China but also in Europe, all these Chinese investments have very big stakes. Indeed, from 1995, a court decision changes the situation and proves the footballers right. The Bosman ruling will have a lasting influence on professional sport, in fact since this court decision, it is no longer possible to limit the number of athletes of the nationalities concerned in a team or professional competition. This means that the richest clubs, therefore, have the right to spend colossal sums and speculate on the best players. This financialization of football is becoming problematic and sees the arrival of investors from rich countries such as the United States, Qatar, Russia, and more recently China [22].

\subsection{Motivations of China to Invest in Football Business}

China is motivated to become a great sports nation. The 2008 Olympic Games accelerated the development of sport in China and enabled the whole world to consider China as a sporting nation in its own right. It promoted several sectors related to sport and more precisely to football such as the standards of sports consumption. In particular by focusing on the most popular sport in the world, football. In the 1990s, they introduced the first foreign players, and thus China has seen a big increase in the popularity of football [23]. 
Jean Humbert et al., Extsv. Rev.; Vol. 2, Issue 1, pp: 3-10, 2022

Since 2015 they have focused on this sport by making reforms around it. These reforms aim to improve clubs and their management to optimize the competition system, strengthen the national team, transform aging infrastructure and increase investment. These reforms are the idea of one man, Xi Jinping. A big football fan and very involved in the development of football in China, he was already staging himself in front of journalists by shooting a ball during his visit to Dublin as vice-president in 2012. For him, the goal is simple, encourage industrialists, investors, public and private companies to invest in this new industry. This goal is also achieved through education. Indeed, for almost 10 years now, the teaching of football has become compulsory in Chinese schools. In addition, in 2025, 50,000 Chinese primaries and middle schools will be picked to promote football among the kids [23].

The goal is to find the future Mbappé or Ronaldo who will allow China to shine as we have seen from Drogba and Anelka were signed by one the Shanghai Shenhua Football Club [24]. The statistics speak for themselves, in 2030 there will be 1 football field for every 10000 inhabitants. In addition, the General Plan of Chinese Football Reform released in 2015 aims to build large stadiums throughout the country. It is one of the most important tasks on the agenda. But it is found that there is a huge urban-rural gap in satisfaction with public sports services. Guangzhou and Shanghai which are coastal cities attract more investment and are better players. The competition with clubs from Western provinces can be high. For China, football can allow them to restore their often-negative image, and more particularly with the coronavirus pandemic. According to a poll made by PEW Research Center, overall, China is viewed negatively by $73 \%$ of people. Thanks to football, this negative perception can perhaps be changed for the better and have both a cultural and a social impact on the world. Chairman Xi Jinping wants his dream to come true, i.e. to compete in, organize and win a World Cup. However, the road is long to hope to lift the golden trophy. This is why Xi is counting on investments from these citizens and thus fulfill the dream of the Chinese population [25][32].

Since the early 2010s, China has faced a slowdown in its growth. The purpose of these investments is to avoid a recession. For that, investors follow the authorities' indications and diversify their activities, which allows them to be well regarded by them. If they don't need to obtain short-term profits, then the acquisition of shares in European clubs can be seen as a start, which does not have the same obstacles as those in the production industry. Investing in Milan, for example, is like investing in tourism and fashion, with profits insight. Chinese investors are aware that they will bring Chinese fans who will not only go to see the match but also spend time and money in the city. Through investment in the club, it benefits also to the city and its surrounding economy and neighboring countries particularly as lately, China offers 150 million dollars to Cambodia for a giant stadium construction [33]. Between respect for state and capitalistic principles, these investors also manage to obtain income via broadcasting rights, paid sites on smartphones which are very popular among young Chinese. Almost half of the Chinese people watch sports on their mobile devices and subscribe to subscriptions or through one-off offers called pay-per-view.

Other motivations are also involved. On the one hand, investors have a long-term goal. They slowly but surely want to build a Made in China football with the knowledge and qualities that can be brought back from Europe. On the other hand, by owning a football club, these investors buy themselves notoriety and reputation among the Chinese public. They become the flagship of the authorities and acquire a certain legitimacy. These new rich, also present in the Gulf countries, are looking to spend their money and be entertained through new ways [34]. However, these numerous investments can generate risks. In general, Chinese football clubs were run through public organizations and chaired by officials with the sole purpose of climbing the party levels. With an ambition outside of football, it is obvious that it is more complex to have football plans in the long term.

With clubs changing presidents regularly, it is difficult to deal with a strong institution. This is the case with Guangzhou City, which has changed its name eight times over the past 26 years and played in no less than 3 different cities. Another prominent example is Beijing Renhe F.C., a Yi League club, China's third division, which has had eight owners and four different cities. Each time the new shareholders bring their mentalities and this notably involves changing the management, the logo, or the colors of the club. If the clubs travel, 
this is certainly not the case with the supporters who are tired of these decisions taken by the managers without consulting the fans. So that doesn't encourage people to take an interest in football. However, clubs are well managed, such as Shanghai Port FC. Founded in 2005 by Xu Genbao, a renowned, passionate coach and former international footballer, Shanghai Port FC is a model of management and training for young players [35], [36].

Unthinkable in Europe, these successive changes would provoke popular movements. This was the case in France, in Bordeaux, when the new American shareholders decided to change the historic logo of the club, angering the supporters. This lack of a strong club with a long history demonstrates the inexperience and youthfulness of the sport in the Middle Kingdom. Profits prevail over sports results. Like the Financial Fair Play introduced by UEFA, China does not have it. However, the Chinese government has put in place certain rules aimed at regulating this growing market. For example, the Chinese Football Association has decided to limit the number of foreign players on the pitch to three. Another rule is the requirement to have a Chinese national goalkeeper. To professionalize young people, the federation also obliges teams to have at least two footballers under 23 years of age play during official matches. But that's not all, the CFA has decided to regulate transfer amounts to limit club debt. Indeed, announced in December 2020, there will be now a salary cap. Chinese nationals' players can earn a maximum of 774,000 dollars per year while foreigners can earn up to 3.69 million dollars per year. Clubs exceeding this amount risk being relegated to the second division [37].

\subsection{Risks and Challenges}

These Chinese investments in Europe generate challenges and many impacts. They can involve risks such as strengthening the bigger clubs and thus abandoning the smaller ones. Low-income clubs can be left behind sportingly but above all economically. If the authorities do not take the lead, then it is likely to worsen over time. For European fans, one of the major risks facing the championships is the Americanization of football. That is to say, attracting supporters no longer to see a match but a show, transforming them into spectators and pushing them to consume. Taking advantage of these factors is possible, as with Espanyol Barcelona which appears to be using their Chinese player Wu Lei as a marketing product and as a gateway to the Chinese market. It even resulted in the opening of three football academies by Espanyol Barcelona in China [38].

Chinese investors have sporting goals, but above all they are economic. They know full well that they will be able to generate profits. Their strategies are thought through for a long time and through the buyout of a club, they, therefore, promote their businesses. In addition, local investors seem less and less interested in investing, so this plays in favor of foreign investors who find relatively affordable clubs where they can therefore arrive with their requirements. These Chinese investments are based on several conditions depending on the percentage of control of the club. However, one of the impacts of Chinese investment in the football industry has brought a debate among many scholars, for example, it has been stated that due to the Covid-19 crisis there has been a reduction in the investment by shareholders. But the goal is always similar, that is to say, to transfer the know-how to the other side of the globe, to build a reputation, and finally to satisfy the Chinese president [39], [40].

These repeated investments causing indebtedness create in the short term a speculative bubble that risks destabilizing European football and these clubs. Seen as an opportunity in the first place, the arrival of these investors from halfway around the world will not benefit everyone. Historic clubs, already in conflict with clubs using petrodollars, may have to go to UEFA and continue to push to regulate the money that is proliferating in sport number one, football.

\section{Conclusion}

The rise of China is happening in all sectors and especially in football. It tries to influence this sport through these investments, whether national, with brand new training centers, the purchase of players, or broadcasting rights. But also international, with the acquisition of clubs or companies related to football. 
Jean Humbert et al., Extsv. Rev.; Vol. 2, Issue 1, pp: 3-10, 2022

The state's asserted desire to become a great football nation, public and private companies must follow the President's wishes. Therefore, its recommended for other nations to have cooperation with China in regards to building a football avenue for win-win situations which involve all parties such as the Chinese offer to Cambodia over $\$ 150$ million to construct a giant stadium which is term as "stadium diplomacy".

\section{Declarations}

\subsection{Acknowledgments}

We would like to thank the Department of School of Economics and Management of Yangtze University and Prof: Wei Junying for her guidance toward this paper.

\subsection{Competing Interests}

The authors declare that there is no conflict of interest to their knowledge that could jeopardize this work.

\subsection{Publisher's Note}

AIJR remains neutral with regard to jurisdictional claims in published maps and institutional affiliations.

\section{How to Cite this Article}

J. Humbert, J. Wei, C. C. Burgos Villa, and G. R. Daru, "China, Aspiration to Become a Football Superpower: What We Need to Know?", Extsv. Rev., vol. 2, no. 1, pp. 3-10, March 2022.

\section{References}

[1] CGTN, "Man finds joy playing cuju, the parent of modern soccer," 2018. https://news.cgtn.com/news/3d3d414e3267544e79457a6333566d54/share_p.html (accessed Aug. 26, 2021).

[2] S. Halphen, Becoming Champions (TV Series 2018- ) - IMDb. 2018.

[3] FIFA, "FIFA Survey: approximately 250 million footballers worldwide," 2001. https://www.fifa.com/who-we-are/news/fifasurvey-approximately-250-million-footballers-worldwide-88048 (accessed Mar. 25, 2021).

[4] V. Despentes, "Obscurs agents de joueurs, dérives financières : enquête sur le foot business," https://www.lesinrocks.com/, 2013, Accessed: Mar. 25, 2021. [Online]. Available: https://www.lesinrocks.com/actu/obscurs-agents-joueurs-derives-financieresenquete-foot-business-3303-11-09-2013/.

[5] LFP, "Ouvert le 16 février 2017, le bureau du football français de Pékin, en Chine, a poursuivi en 2018 la mise en œuvre de la feuille de route établie par la FFF et la LFP.," 2019. https://www.lfp.fr/Articles/ACTUALITÉS/2019/02/08/une-annee-2018-prometteuseen-chine (accessed Mar. 24, 2021).

[6] C. Palierse, "Le bureau du foot français à Pékin, un enjeu de «business » pour la LFP," 2017. https://www.lesechos.fr/2017/02/lebureau-du-foot-francais-a-pekin-un-enjeu-de-business-pour-la-lfp-160919 (accessed Mar. 25, 2021).

[7] A. Alyce, "Comment le Ministère des Sports appuie le développement du foot français ?," 2017. https://www.ecofoot.fr/interviewcollectif-football-france-2241/ (accessed Mar. 25, 2021).

[8] P. Stebbings, "China wants football to be 'bridge with the world': top FA official," 2020. https://au.news.yahoo.com/china-wantsfootball-bridge-world-035908305.html?guccounter=1 (accessed Mar. 25, 2021).

[9] J. Copping, "Chinese Super League implements rule to limit foreign players," 2018. https://sportslawandtaxation.com/news/647chinese-super-league-implements-rule-to-limit-foreign-players (accessed Mar. 25, 2021).

[10] E. Bayle, "Le grand bond en avant du football chinois," 2018. https://www.letemps.ch/sport/grand-bond-football-chinois (accessed Mar. 25, 2021).

[11] WSJ, "China's Evergrande Taobao is the World's Most Highly Valued Soccer Team ... Or Is It?," 2016. https://www.wsj.com/articles/BL-CJB-28842 (accessed Mar. 25, 2021).

[12] Transfermarkt, "Guangzhou FC - Club profile | Transfermarkt," 2019. https://www.transfermarkt.com/guangzhoufc/startseite/verein/10948 (accessed Mar. 25, 2021).

[13] M. Rohde and C. Breuer, "Competing by investments or efficiency? Exploring financial and sporting efficiency of club ownership structures in European football," Sport Manag. Rev., vol. 21, no. 5, pp. 563-581, Nov. 2018, doi: 10.1016/j.smr.2018.01.001.

[14] S. Carp, "China Sports Media rejigs Chinese Super League rights deal," 2018. https://www.sportspromedia.com/news/china-sportsmedia-rejigs-chinese-super-league-rights-deal (accessed Mar. 25, 2021).

[15] Tmtpost, "Stories Behind A.C. Pavia's Bankruptcy, the First Chinese-Acquired Italian Football Club," 2016. https://www.tmtpost.com/2504773.html (accessed Mar. 25, 2021).

[16] M. Iaria, "Geopolitica e pallone, la frenata della Cina," 2017. https://www.gazzetta.it/Calcio/Serie-A/28-08-2017/geopoliticapallone-frenata-cina-scenari-220167617035.shtml (accessed Mar. 25, 2021).

[17] C. Ribagorda, "Soxna, la empresa que forma futbolistas chinos en Madrid, entra en concurso de acreedores," 2018. https://okdiario.com/economia/soxna-empresa-que-forma-futbolistas-chinos-madrid-entra-concurso-acreedores-3393949 (accessed Mar. 25, 2021).

[18] A. Jourdan, "China’s Suning buying majority stake in Inter Milan for $\$ 307$ million," 2016. https://www.reuters.com/article/ussoccer-inter-milan-suning-idUKKCNOYR03T (accessed Mar. 25, 2021). 
[19] J. Cardoze, "Chine, la grande offensive," 2021.

[20] T. Y. Jones and D. Thomas, "China's Wanda to buy U.S. cinema chain AMC for \$2.6 billion | Reuters," 2012. https://www.reuters.com/article/us-amcentertainment-idUSBRE84K03K20120521 (accessed Mar. 25, 2021).

[21] B. Fritz and L. Burkitt, “China's Dalian Wanda Buys Legendary Entertainment for \$3.5 Billion," 2016. https://www.wsj.com/articles/chinas-dalian-wanda-buys-legendary-entertainment-for-3-5-billion-1452567251 (accessed Mar. 25, 2021).

[22] D. Schmidt, "The effects of the Bosman-case on the professional football leagues with special regard to the top-five leagues," 2007.

[23] J. Sullivan, “China's Football Dream," p. 2020, [Online]. Available: https://www.nottingham.ac.uk/asiaresearch/documents/cso-ebook.pdf.

[24] China.org, "Hero's welcome for Drogba," 2012. http://www.china.org.cn/sports/2012-07/15/content_25910201.htm (accessed Sep. 16, 2021).

[25] L. Huang, "Research on effect of beijing post-olympic sports industry to China's economic development," in Energy Procedia, Jan. 2011, vol. 5, pp. 2097-2102, doi: 10.1016/j.egypro.2011.03.362.

[26] Y. Liang, "The emerging labour market and transformation from state amateurs to professional athletes," Communist PostCommunist Stud., vol. 52, no. 4, pp. 379-390, Dec. 2019, doi: 10.1016/j.postcomstud.2019.10.005.

[27] S. Leng, "China's soccer-mad President Xi Jinping's passion for 'the beautiful game' sparked while a child," 2015. https://www.scmp.com/news/china/policies-politics/article/1871444/chinas-soccer-mad-president-xi-jinpings-passion (accessed Mar. 25, 2021).

[28] J. Xu, C. Gao, and J. Zhao, "National football promotion in China: Opportunities and challenges in public health," J. Sport Heal. Sci., vol. 5, no. 2, pp. 250-251, Jun. 2016, doi: 10.1016/j.jshs.2016.04.006.

[29] L. Shi and R. An, "An Optimization design Approach of Football Stadium Canopy Forms Based On Field Wind Environment Simulation," Energy Procedia, vol. 134, pp. 757-767, Oct. 2017, doi: 10.1016/j.egypro.2017.09.575.

[30] X. Guo, A. Hu, J. Dai, D. Chen, W. Zou, and Y. Wang, "Urban-rural disparity in the satisfaction with public sports services: Surveybased evidence in China," Soc. Sci. J., vol. 55, no. 4, pp. 455-462, Dec. 2018, doi: 10.1016/j.soscij.2018.05.003.

[31] BBC, “China aims to become football superpower 'by 2050," 2016. https://www.bbc.com/news/world-asia-china-36015657 (accessed Mar. 25, 2021).

[32] L. Silver, K. Devlin, and C. Huang, "Unfavorable Views of China Reach Historic Highs in Many Countries | Pew Research Center," 2020. https://www.pewresearch.org/global/2020/10/06/unfavorable-views-of-china-reach-historic-highs-in-many-countries/ (accessed Mar. 25, 2021).

[33] Insider, "China Just Gifted Cambodia a New \$150 Million Stadium: Photos,” 2021. https://www.insider.com/china-gift-cambodiastadium-morodok-techno-diplomacy-photos-2021-9 (accessed Sep. 17, 2021).

[34] N. Peng, A. Chen, and K.-J. Kwon, “Chinese football fans' intentions to visit Europe,” Ann. Tour. Res., vol. 61, pp. 234-238, Nov. 2016, doi: 10.1016/j.annals.2016.08.006.

[35] Z. Hu, "Renhe struggle to remain relevant in Beijing as relegation looms," 2019. https://news.cgtn.com/news/2019-08-15/Renhestruggle-to-remain-relevant-in-Beijing-as-relegation-looms-JaWpRQwZhe/index.html (accessed Oct. 29, 2021).

[36] Y. Wang, "Guangzhou R\&F officially changed its name to Guangzhou City Team, which is"tact against" with Evergrande's new name? - yqqlm," 2020. https://www.yqqlm.com/2020/12/guangzhou-rf-officially-changed-its-name-to-guangzhou-city-teamwhich-istact-against-with-evergrandes-new-name/ (accessed Oct. 29, 2021).

[37] T. A. Press, "Chinese Super League set to lose some of its overseas luster with new salary cap introduced," 2021. https://www.firstpost.com/sports/chinese-super-league-set-to-lose-some-of-its-overseas-luster-with-new-salary-cap-introduced9183191.html (accessed Mar. 25, 2021).

[38] F. Projects, “The academies of RCD Espanyol de Barcelona are now in every continent," 2020. https://newsletter.laliga.es/globalfutbol/academies-of-espanyol-in-every-continent (accessed Mar. 25, 2021).

[39] Y. Wang, Y. Wang, and M.-X. Li, "Regional characteristics of sports industry profitability: Evidence from China's province level data," Phys. A Stat. Mech. its Appl., vol. 525, pp. 946-955, Jul. 2019, doi: 10.1016/j.physa.2019.03.066.

[40] J. Hammerschmidt, S. Durst, S. Kraus, and K. Puumalainen, "Professional football clubs and empirical evidence from the COVID19 crisis: Time for sport entrepreneurship?," Technol. Forecast. Soc. Change, vol. 165, p. 120572, Apr. 2021, doi: 10.1016/j.techfore.2021.120572.

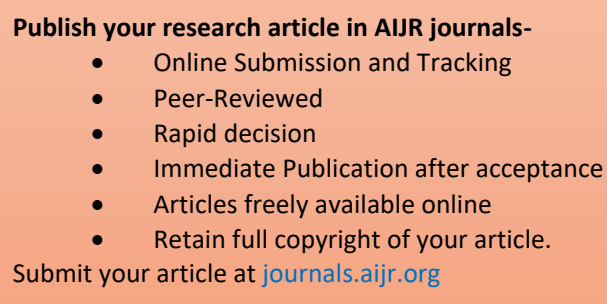

\section{Publish your books with AIJR publisher-}

- $\quad$ Publish with ISBN and DOI.

- Publish Thesis/Dissertation as Monograph.

- Publish Book Monograph.

- $\quad$ Publish Edited Volume/ Book.

- Publish Conference Proceedings

- Retain full copyright of your books. Submit your manuscript at books.aijr.org 